<要 約 > 近年, 急性心筋梗塞の血栓溶解療法として大量のウロキナーゼ (UK) を経静脈的に投与す る全身線溶療法でも血栓が溶解され血流が再開し，梗塞範囲縮小に有効なことが報告されている．今回 我々は発症 6 時間以内に早期収容された 60 歳以上の初回急性貫壁性梗塞33例を通常治療群18例（C群） と, ウロキナーゼ 96 万単位急速投与群 15 例 (UK 群) にわけ, 老年者急性心筋梗塞における UK 療法の 有効性, 安全性を検討した.

C 群で男, 前壁梗塞が多い傾向がみられたが, 平均年齢, 発症より CCU 入室までの時間, 入院時心不 全重症度分類は両群で差を認めなかった。 UK 群では重篤な出血症状は認めなかった。発症 7 日後の急性 期死亡率はC 群 $44 \%$ ( 8 例), UK 群13\% (2 例) で, UK 群で少ない傾向を認め, 特にショック死はC 群 4 例に対し, UK 群では認めなかった。急性期死亡例を除いた C 群10例（前壁 6 例, 下壁 4 例), UK 群13例（前壁 5 例，下壁 8 例）の検討では心電図上，入院時の $\Sigma \mathrm{ST}$ および QRS score, CPK, CPK-MB 最高值および最高值到達時間, 入院時および $5 \sim 6$ 病日における血行動態諸指標, RN アンジオグラムに よる発症約 1 カ月後の左室駆出率には両群間で差を認めなかった. $\mathrm{SST}$ 下降率は第 2 病日 C 群一 $41.6 \pm$ $7.4 \%$, UK 群一 $68.1 \pm 5.6 \%$ と UK 群にて有意に大で $(\mathrm{p}<0.05)$, UK 群では $\Sigma \mathrm{ST}$ は 7 病日まで持続的 に下降した。そして 5 病日の QRS score はC 群 $4.6 \pm 0.8, \mathrm{UK}$ 群 $2.0 \pm 0.7$ UK 群では有意に低かった

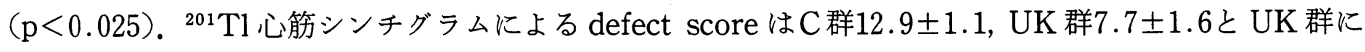
て有意に低かった $(\mathrm{p}<0.025)$.

以上より経静脈的 UK 大量療法は老年者急性心筋梗塞でも安全に施行でき, 本療法により梗塞巣の縮 小が推定され, 急性期死亡率も軽減された.

Key words : 急性心筋梗塞, 経静脈的血栓溶解療法, ウロキナーゼ

急性心筋梗塞の発生機序については種々の議論があ るが冠動脈硬化を基盤として血栓が一次的あるいは二 次的に関与していると考兄られている。そこで冠動脈 内に生じた血栓を早期に溶解する血栓溶解療法は急性 心筇梗塞の治療上, 合目的であり, 早期に冠血流が再 開されれば梗塞巣の縮小が期待できる。

近年, 急性心筋梗塞の血栓溶解療法として選択的に 冠動脈内にストレプトキナーゼ（SK）あるいはウロキ ナーゼ (UK) を投与する Percutaneous Transluminal Coronary Recanalization (PTCR)のみならず, 大量 の SK あるいはUKを経静脈的に投与する全身線溶 療法でも血栓が溶解し, 血流が再開され, 梗塞範囲縮

M. Sakai, S. Matsushita, K. Ueda, K. Kuramoto:

東京都老人医療センター循環器科

* 東京都多摩老人医療センター循環器科

受付日. 1986. 11. 17 .
小に有効なことが報告されている1) 4).

そこで今回我々は老年者急性心筋梗塞に拈いても容 易に施行できる経静脈的 UK 療法の有効性, 安全性を 検討したので報告する。

\section{対 象（表 1 )}

最近 5 年間に東京都老人医療センターCCUに入院 した 60 歳以上の初回貫壁性梗塞 103 例中, 発症 6 時間以 内の早期入院例は 33 例， $32 \%$ であった。このうち18例 （男 12 , 女 6 例, 平均年齢 75.5 歳）に酸素吸入, 補液, 抗不整脈薬，鎮痛鎮静薬，カテコールアミン，亜硝酸 薬, 利尿薬などによる通常治療を行い(以下 C 群と略), 昭和58年 9 月以後に入院した 15 例（男 6 , 女 9 例, 平 均年齢76.1歳) にUK 療法を施行した（以下 UK 群と 略). 梗塞部位は C 群前壁14例, 下壁 4 例, UK 群前壁 7 例, 下壁 8 例であり, C 群で男, 前壁梗塞が多い傾 
表 1 対象

\begin{tabular}{|c|c|c|}
\hline & $\begin{array}{l}\text { 通常治療群 } \\
\text { (C 群) }\end{array}$ & $\begin{array}{c}\text { ウロキナーゼ投与群 } \\
\text { (UK 群) }\end{array}$ \\
\hline 例 数 & 18 & 15 \\
\hline 男 /女 & $12 / 6$ & $6 / 9$ \\
\hline 平均年齢 & $75.5 \pm 1.4$ & $76.1 \pm 1.4$ \\
\hline 梗 塞 部 位 & & \\
\hline 前 壁 & 14 & 7 \\
\hline 下 壁 & 4 & 8 \\
\hline Killip 分類 & & \\
\hline I & 11 & 11 \\
\hline II & 4 & 3 \\
\hline III & 1 & 0 \\
\hline IV & 2 & 1 \\
\hline $\begin{array}{r}\text { 発症より CCU } \\
\text { 入室までの時間 } \\
\text { (分) }\end{array}$ & $187 \pm 30.7$ & $160 \pm 23.4$ \\
\hline
\end{tabular}

mean $\pm \mathrm{SEM}$

向がみられたが有意ではなかった。発症よりCCU 入 室までの時間はC 群 $187 \pm 30.7$ 分, UK 群 $160 \pm 23.4$ 分 と差はなく，入院時心不全重症度分類 (Killip 分類)で も両群に差を認めなかった。

\section{方 法}

\section{1）UK 投与法}

CCU 入室後 (心筋梗塞発症平均 220 分後)，ただちに ヘパリン 3,000 単位静注ののち, 生食 $100 \mathrm{~m} l$ に溶解し たUK 96万単位を15分で急速に投与した。 そして多く の症例で UK 治療開始後, ヘパリン, ワーファリンに よる抗凝固療法を継続した。また必要に応じC群と同 様，抗不整脈薬，鎮痛鎖静薬，カテコールアミン，亜 硝酸薬, 利尿薬などを併用した。 UK は興和新薬, 鐘紡 薬品製のものを使用した。な挔UK 療法の実施にあ たっては出血性潰瘍または出血傾向のある患者, 他の 重篤な合併症のある患者は対象より除外した。

2) 評価法

両群の比較評価は，(1)発症 7 日後の急性期予後，(2) 臨床検査值，(3)12誘導心電図に括ける $\Sigma \mathrm{ST} ， \mathrm{QRS}$ score の変化, (4)急性期血行動態諸因子, (5)慢性期に打 ける ${ }^{201} \mathrm{Tl}$ 心筋シンチグラム, radionucide angiocardiogramで行った.

心電図 $\Sigma S T$ に变化しては入院直後より連続的に記 録した12誘導心電図を用いて前壁梗塞では $V_{1} \sim V_{6}$ 誘 導, 下壁梗塞では II, III, aVF 誘導を用いてそれぞれの $\mathrm{ST}$ 上昇の総和 $(\boldsymbol{N S T})$ ，㧊よび Wagner 法 ${ }^{5}$ による QRS score を算出し， 7 日間計測してその変化を両群
間で比較した。

血清酵素值に関しては入院直後より 4 時間間隔で末 梢静脈より採血し，血清 CPK, CPK-MB, GOT, LDH の各最高值, CPK, CPK-MB 最高値到達時間, CPK 正 常化到達時間を両群で比較した。すた入院直後すなお ち治療前に Swan-Ganz カテーテルを用いて血行動態 諸因子（心係数，肺動脈楔入圧，1 回心仕事係数）を 測定し，そして血行動態が安定した $5 \sim 6$ 病日の值と を両群で比較した。

発症約 1 カ月後の慢性期に ${ }^{201} \mathrm{Tl}$ 心筋スキャン, radionuclide angiocardiography を施行し, defect score $\left({ }^{201} \mathrm{Tl}\right.$ 心筋シンチグラムの anterior, LAO $30^{\circ}$, LAO $60^{\circ}$, lateral の各像を 3 等分し, 各領域の defect の面積を定性的に以下のごとく点数化し，総和した。 0 点: no defect, 1 点: defect $か$ 全体の $1 / 2$ 以下, 2 点： defect が $1 / 2$ 以上で total 以下, 3 点: defect が total)，左室および右室駆出率（LVEF, RVEF）を両 群で比較した。

\section{成 績}

1）発症後 7 日後の急性期予後（表 2 ）

急性期死亡例は C 群, UK 群ともにすべて前壁梗塞 例であった。C群では 8 例が死亡し急性期死亡率は $44 \%$ に対し, UK 群では 2 例が死亡し, 急性期死亡率は 13\%とC群に比べ減少傾向を認めたが，統計学的には 有意の差はなかった。同様に前壁梗塞例に抽ける急性 期死亡率も C 群 $57 \%$ に対し UK 群 $29 \%$ と UK 群にて 減少傾向を認めたが，統計学的には有意の差はなかっ た。死因ではC 群でショックを 4 例に認めたが, UK 群 ではショック死を認めなかった。な招 UK 群では重篤 な出血症状を特に認めず, UK 投与後, 心室細動, 徐脈 性不整脈などの reperfusion arrhythmia と思われる ものは 5 例（前壁梗塞 1 例，下壁梗塞 4 例）に認めら れた。

表 2 急性期予後

\begin{tabular}{|c|c|c|c|c|c|c|}
\hline (n) 死 因 & ショック & 心破裂 & 心不全 & 計 & 死亡率 & \begin{tabular}{|l} 
前譬梗塞例の \\
死亡率
\end{tabular} \\
\hline $\begin{array}{c}\text { C 群 (18) } \\
\text { 前 壁(14) }\end{array}$ & 4 & 3 & 1 & $\begin{array}{c}8 \\
(8)\end{array}$ & $44 \%$ & $57 \%$ \\
\hline $\begin{array}{l}\text { UK 群 (15) } \\
\text { 前 壁( }(7)\end{array}$ & 0 & 1 & 1 & $\begin{array}{c}2 \\
(2)\end{array}$ & $13 \%$ & $29 \%$ \\
\hline $\begin{array}{lr}\text { 計 } & (33) \\
\text { 前 } & \text { 壁(21) }\end{array}$ & 4 & 4 & 2 & $\begin{array}{l}10 \\
(10)\end{array}$ & $30 \%$ & $48 \%$ \\
\hline$\left(\chi_{\mathrm{c}}^{2}=1.99\right)$ & & & & $(\lambda)$ & 42) & $\left(\chi_{\mathrm{c}}^{2}=0.6\right)$ \\
\hline
\end{tabular}




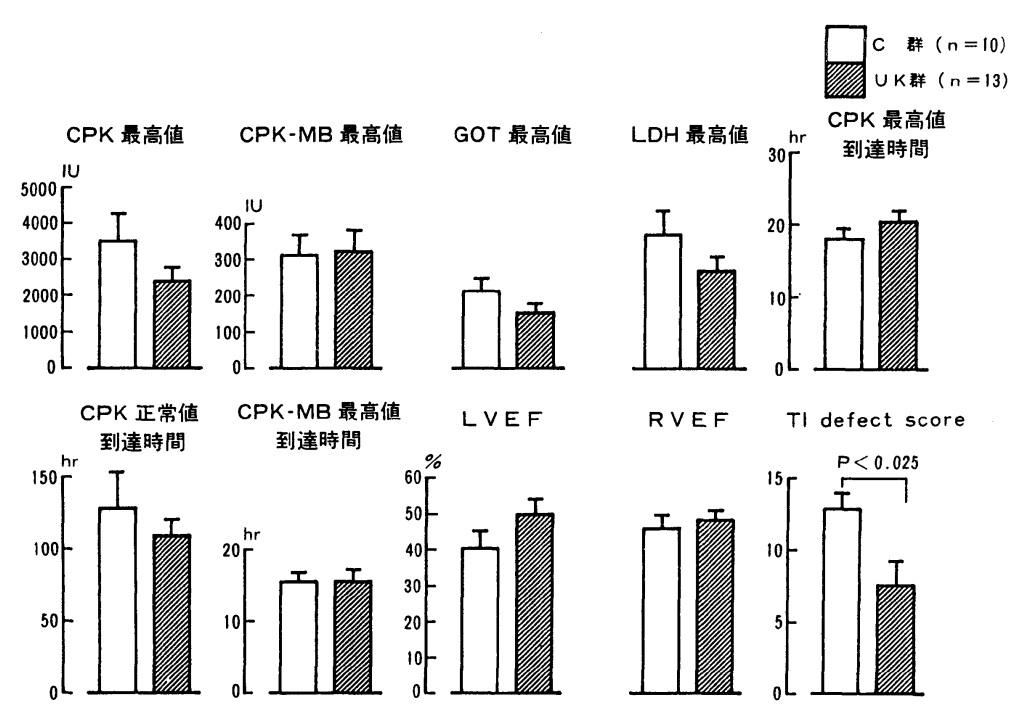

図 1 臨床検查値の比較

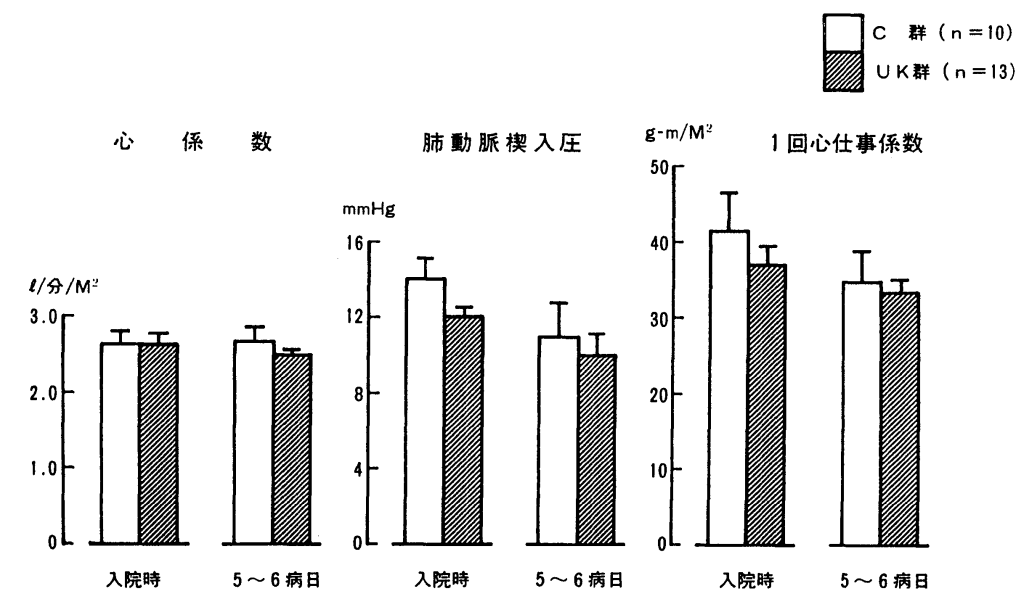

図 2 血行動態の比較

次に急性期死亡例を除いたC 群10例（前壁 6 例，下 壁 4 例), UK 群13例（前壁 5 例，下壁 8 例）について 臨床所見，心電図所見を対比検討した。

2）臨床検查値の比較

両群の臨木検査值を図 1 に示す。CPK, CPK-MB, GOT, LDH の各酵素値の最高值和よび CPK 最高值, CPK-MB 最高值, CPK 正常值到達時間は両群で有意 の差を認めなかった。慢性期の左室, 右室駆出率も両 群で差を認めなかったが, ${ }^{201} \mathrm{Tl}$ 心筋シンチグラムによ

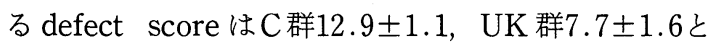
UK 群にて有意に低值であった $(\mathrm{p}<0.025)$.

3）血行動態の比較
両群の入院時および 5 ないし 6 病日の血行動態を図 2 に示す。心係数は入院時和よび 5 ないし 6 病日とも 両群で差を認めなかった. 肺動脈楔入王, 1 回心仕事 係数は両群とも入院時に比べ 5 ないし 6 病日では減少 傾向を認めたが, 両群間で有意差なく, 各指標の变化 率にも差を認めなかった。

4) $\Sigma \mathrm{ST}, \Sigma \mathrm{ST}$ 変化率の比較

両群の入院時および 7 病日までの $\Sigma \mathrm{ST}, \Sigma \mathrm{ST}$ 変化 率を図 3 に示す。入院時 $\Sigma S T$ は両群間に执いて有意 差を認めないが，UK群では経時的に $\Sigma$ ST は下降し， 5，6，7病日に扤いて両群間に有意の差を認めた。 図 3 下段は入院時の $\Sigma$ ST に対する各病日の $\Sigma S T$ 変 


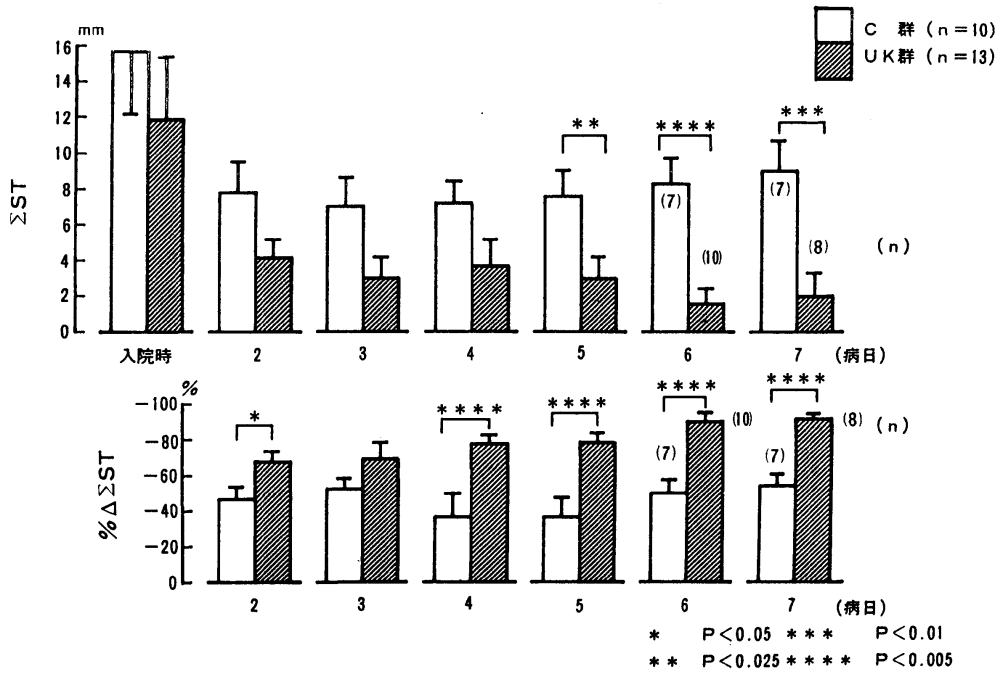

図 $3 \Sigma \mathrm{ST}$ および $\Sigma \mathrm{ST}$ 変化率の比較

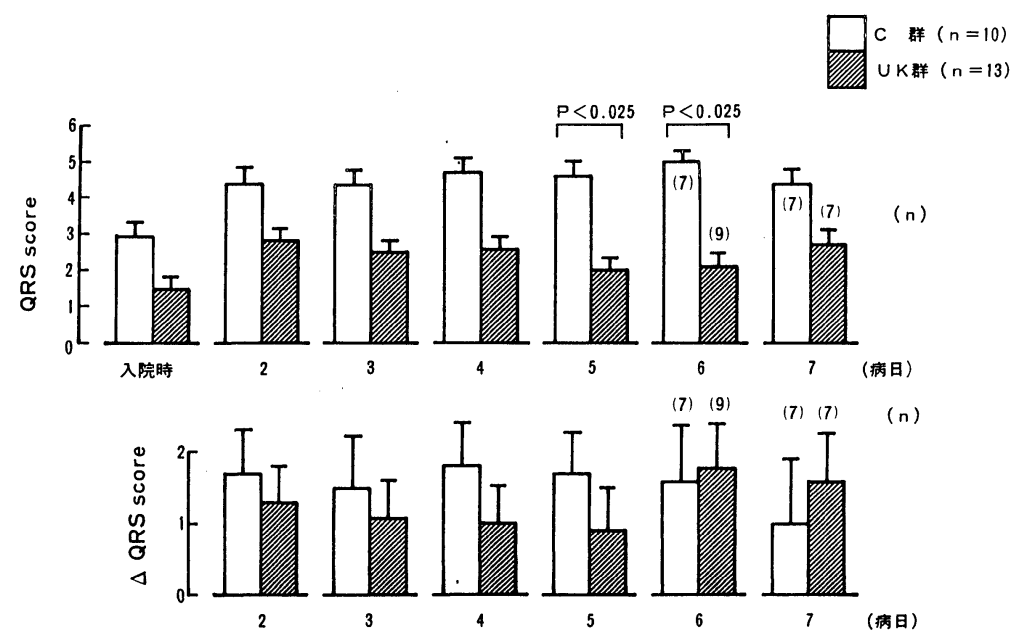

図4 QRS score 执よび $\Delta \mathrm{QRS}$ scoreの比較

化率を示す。第 2 病日ではC群一 $41.6 \pm 7.4 \%$ に対し,

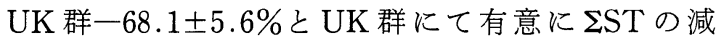
少は大きく, 4〜 7 病日でも UK 群はC群に比べ $\Sigma S T$ の下降率は大であった。

5) QRS score 扎よび $\Delta \mathrm{QRS}$ score の比較

両群の入院時および 7 病日までの QRS scoreおよ び $\Delta \mathrm{QRS}$ score を図 4 に示す. 入院時 QRS score は両 群間で有意の差を認めないが，5病日においてC群で はUK 群に比し, 有意に QRS score が大であった。図 4 下段の入院時の QRS scoreに対する各病日の $\triangle \mathrm{QRS}$ score は各病日に拈いて両群間に有意の差を認 めなかった。
考案

急性心笳梗塞の早期に責任冠動脈の血流再開をはか る血栓溶解療法は，近年多くの施設で実施され，その 成績が報告されている.特に PTCR は1979年 Rentrop $5^{6)}$ が SKを用いて臨床的に応用して以来, 多くの実 証成績が報告されその有用性が確立されつつある。し かし PTCR を施行するには急性期の冠動脈造影によ る責任冠動脈を決定する必要があり，急性期の冠動脈 造影に伴う Risk も多く，施行可能な施設の制限およ び治療開始までに準備時間を要するなどの問題点があ る. 
これに対し静脈内投与により血检溶解療法は血栓溶 解剂の血栓部位への到達, 濃度拈よび出血傾向といら 問題はあるものの簡便な方法で梗塞発症後短時間内に 実施できるという利点があり, PTCR に近い効果が得 られれば理想的な治療法といえる。

1982年以来, 欧米では SK の静脈内大量投与が試み られ, 最近では PTCR と静脈内投与を比較した成績も 数多く報告されている。静脈内投与では PTCR の 2 〜 4 倍の SKを用いたそれらの血栓溶解率は PTCR で70\%台，静脈内投与で $40 \sim 60 \%$ 台と報告されてい る7) 10). 本邦においては血栓溶解剂としてUKが用い られるが, 同じく PTCR と静脈内投与で血栓溶解率を 比較した成績では石田ら ${ }^{11)}$ は $72 \%$ 対 $67 \%$ ，鬼倉ら ${ }^{12)}$ $76 \%$ 対 $73 \%$ と静脈内 UK 大量投与はPTCR に匹敵す る血栓溶解率を示し, 局所壁運動の検討からも梗塞巣 縮小に有効なことが示されている.

今回我々は発症 6 時間以内の比較的高齢の急性心筋 梗塞例を対象にUK 96 万単位の大量急速静脈内投与 を試み, 通常治療群と比較した。 多くの例で UK 投与 後, プロトロンビン時間, 部分トロンボプラスチン時 間の延長, フィブリノーゲンの低下, FDP の増加など 凝固線溶系の変動を認めたが, 重篤な出血症状を認め ず，また血流再開通に伴うと思われる不整脈も一過性 であり, CCUに沶いて対処でき, 老年者急性心筋梗塞 においてもUK の大量静脈内投与は安全に施行でき た。

急性期に冠動脈造影をしないで血流再開の効果を判 定する方法としては，従来より reperfusion arrhythmia や, CPK 最高値到達時間の短縮化が指摘されてい るが, 最近の検討ではこれらは満足できる指標でなく, 長尾ら ${ }^{13)}$ はST 変化が最も有効な指標であると報告し ている。我々の成績に捛いても CPK, CPK-MB 最高值 到達時間とも UK 群, 対照群では差はなかったが, UK 群では心電図上, $\Sigma \mathrm{ST}$ の減少, $\Sigma \mathrm{ST}$ 変化率はともに大 で, UK 投与による血流再開の効果をうかがわせた。 そ して UK 群では QRS score, ${ }^{201} \mathrm{Tl}$ defect score と有意 に小さく梗塞巣縮小が推定され，急性期死亡率の減少 傾向も認められた。

しかしながら慢性期の左心機能 (LVEF) はUK 群 $49.9 \pm 4.2 \%$ に対し, 対照群 $40.3 \pm 4.7 \%$ 之有意差を認 めなかった。 このことは抢そらくUK大量投与で血流 の再開通が得られても高度の残存狭窄が残っているた めや，同部に再閉塞を抗こして心機能を十分に温存す るだけの血流を保てないためと思われる，事実，慢性
期に冠動脈造影を施行した UK 群の 2 症例（前壁およ び下壁梗塞各 1 例)では, 各々, 前下行枝近位部に $90 \%$ 狭窄, 右冠動脈近位部に完全閉塞を認めた。これらのこ とから血栓溶解療法のみでは十分でなく, 最近では高 度狭窄を残す例では Percutaneous Transluminal Coronary Angioplasty (PTCA) や冠動脈バイパス術 を施行することにより心機能や予後の改善を得ること が期待されている. 今後は老年者心筋梗塞例に招いて も積極的にこれら併用療法も考慮されるべさと思われ る.

\section{結 論}

発症 6 時間以内に早期収容された老年者急性心筋梗 塞33例を通常治療群 18 例（C群）とウロキナーゼ 96 万 単位急速投与群15例 (UK 群) にわけ, UK 療法の効果 を検討し, 以下の結論を得た。

1. 経静脈的 UK 急速大量療法は老年者急性心筋梗 塞でも安全に施行でき, 重篤な出血症状は認めなかっ た.

2. UK 投与群ではC 群に比し， $\Sigma S T$ の下降率は有 意に大で, QRS score, ${ }^{201} \mathrm{Tl}$ defect score も有意に小 さく，虚血および梗塞巣の縮小が推定された。

3. UK 投与群では急性期死亡率の減少傾向を認め, 特にショック死は認められなかった。

\section{文献}

1) Spann JF, Sherry Carbello BA, Mann RH, McCann WD, Gault JH, Gentzler RD, Rosenberg KM, Maurer AH, Denenberg BS, Warner HF, Rubin RN, Malmud LS, Comerota A: Highdose, brief intravenous streptokinase early in acute myocardial infarction. Am Heart J 104 : 939-945, 1982.

2) Schröder R, Biamino G, Leitner ERV, Linderer $\mathrm{T}$, Brüggemann $\mathrm{T}$, Heitz $\mathrm{J}$, Vöhringer $\mathrm{HF}$, Wegscheider $\mathrm{K}$ : Intravenous short-term infusion of streptokinase in acute myocardial infarction. Circulation $67: 536-548,1983$.

3) Ganz W, Geft I, Shah PK, Lew AS, Rodriguez L, Weiss T, Madddahi J, Berman DS, Charuzzi Y, Swan HJC: Intravenous streptokinase in evolving acute myocardial infarction. Am J Cardiol 53 : 1209-1216, 1984.

4) Mathey DG, Schofer J, Sheehan FH, Becher H, TIlsner V, Dodge HT : Intravenous urokinase 
in acute myocardial infarction. Am J Cardiol $55: 878-882,1985$.

5) Wagner GS, Freye CJ, Palmeri ST, Roark SF, Stack NC, Ideker RE, Harrell FE, Selvester $\mathrm{RH}$ : Evaluation of a QRS Scoring system for estimating myocardial infarct size. I. Specificity and observer agreement. Circulation $65: 342$ -347, 1982.

6) Rentrop KP, Blanke H, Karsch KR, Wiegand V, Köstreing $\mathrm{H}$, Oster $\mathrm{H}$, Leitzz $\mathrm{K}$ : Acute myocardial infarction. Intracoronary application of nitroglycerin and streptokinase in combination with transluminal recanalization. Clin Cardiol 2 : 354-363, 1979.

7) Blunda M, Wolf NM, Singh S, Mandelkorn J, Kersh R, Pickering N, Schechter J, Rodgers D, Workman M, Meister SG: Intravenous vs intracoronary streptokinase to reopen occluded coronary arteries-preliminary results. Clin Res $30: 6664,1982$.

8) Rogers WI, Mantle JA, Hood WP Jr, Baxley WA, Whitlow PL, Reeves RC Soto B: Prospective randomized trial of intravenous and intracoronary streptokinase in acute myocar- dial infarction. Circulation $68: 1051-1061$, 1983.

9) Alderman EL, Jutzy KR, Berte LE, Miller RG, Friedman JP, Creger WP, Eliastam M : Randomized comparison of intravenous versus intracoronary streptokinase for myocardial infarction. Am J Cardiol 54 : 14-19, 1984.

10) Valentine RP, Pitts DE, Brooks-Brunn JA, Williams JG, Hove EV, Schmidt PE: Intravenous versus intracoronary streptokinase in acute myocardial infarction. Am J Cardiol 55 : $309-312,1985$.

11）石田敬典, 木下禎彦, 林 康彦, 吉田 修, 柳原 薰, 網岡英世, 岡 裕三, 桧山桂子, 土谷太郎：ウ ロキナーゼの局所療法と全身投与の比較検討. 最 新医学 $40: 870-874,1985$.

12）鬼倉俊一郎, 上松瀬勝男, 鈴木裕太郎, 石川淳一, 長尾 建, 佐藤和義, 安藤隆夫, 佐藤洋一, 瀬戸博 美, 岩崎昌之, 梶原長雄 : 局所投与と全身投与の血 栓溶解率による比較. 最新医学 $40: 880$ - 884 , 1985.

13）長尾 建, 上松瀬勝男, 梶原長雄：急性心節梗塞の 血检溶解療法における血流再開の効果判定の検 討. 日内会誌 $73: 56-64,1984$. 
Abstract

\title{
Intravenous Short-Term Coronary Thrombolysis by a High-Dose Urokinase in Aged Patients with Acute Myocardial Infarction
}

\author{
Makoto Sakai, Satoru Matsushita, Keiji Ueda and Kizuku Kuramoto
}

In order to investigate whether a high-dose, rapid intravenous infusion of urokinase (UK) is a safe and efficient therapy in aged patient with acute myocardial infarction (AMI), electrocardograms, serum enzyme activities, hemodynamics, 201-T1 myocardila scintigrams and radionuculide angiocardiograms were studied in two groups of patients over 60 yeras of age who were admitted within 6 hours of the onset of symptoms of AMI. Eighteen patients received conventional therapy (C group) and 15 patients received a high-dose rapid infusion of UK (960,000 IU) intravenously (UK group). The numbers of male patients and patients with anterior wall infarction were slightly greater in the $C$ group than in the UK group. Mean age, time from the onset of symptoms to admission, and distribution of Killip's classification on admission did not differ between the two groups. Bleeding complications were not observed in the UK group. The mortality rate after 7 days from the onset of AMI tended to be lower in the UK group (13\%) than in the $\mathrm{C}$ group (44\%). Sum of ST elevation and QRS

Division of Cardiology, Tokyo Metropolitan Geriatric Hospital score on admission, peak $\mathrm{CPK}$ and $\mathrm{CPK}-\mathrm{MB}$ levels, time to peak levels, hemodynamics (cardiac index, pulmonary capillary wedge pressure and stroke work index) on admission and on the 5th or 6th day after admission, and left ventricular ejection fraction in the convalescent phase did not differ between the two groups. The decreasing rate of sum of ST elevation on the 2 nd day after admission was significantly greater in the UK grop than in the $C$ group $(-68.1 \pm 5.6 \%$ vs $-41.6 \pm 7.4 \%$, $\mathrm{p}<0.05)$ and sum of ST elevation decreased serially until the 7th day after admission in the UK group. QRS scores on the 5th day after admission were significantly lower in the UK group than in the $C$ group $(2.0 \pm 0.7$ vs $4.6 \pm$ $0.8 \mathrm{p}<0.025)$. Defect scores assessed qualitatively from 201-Tl myocardial scintigrams were significantly lower in the UK group than in the $C$ group ( $7.7 \pm 1.6$ vs $12.9 \pm$ $1.1 \mathrm{p}<0.025)$. Thus, thrombolysis with a high-dose rapid infusion of UK was safe and effective in limiting myocardial injury in aged patients with acute myocardial infarction.

key words: acute myocardial infarction, intravenous coronary thrombolysis, urokinase

(Jpn J Geriat 24: 354-360, 1987) 